\title{
Los campamentos romanos de Astorga y León
}

\author{
Ángel Morillo Cerdán ${ }^{1}$ \\ (Universidad de León)
}

\begin{abstract}
RESUMEN ABSTRACT
El notable incremento de las

The significant increase of

intervenciones arqueológicas en contextos archaeological interventions in Roman militares romanos experimentado durante la última en la península ibérica, especialmente en el cuadrante noroeste, ha propiciado una renovación casi total en este campo científico. Partiendo del análisis de los nuevos datos arqueológicos conocidos, presentamos aquí las novedades sobre los campamentos de la legio $X$ gemina en Astorga y de las legiones VI victrix y VII gemina en León. military contexts experienced in the Iberian Peninsula during the last decade, and more specifically in the NorthWestern quadrant, has triggered a nearly total renovation in this scientific field. Based on the analysis of the new archaeological data revealed, we herein present the news about the legionary fortresses of the legio X gemina at Astorga and the legions VI victrix and VII gemina at León.
\end{abstract}

\section{PALABRAS CLAVE}

Arqueología militar romana; ejército romano; campamentos legionarios; Astorga; León.

\section{KEY WORDS}

Roman military archaeology; Roman Army; legionary fortresses; Astorga; León.

Las guerras cántabras (29-19 a. C.) obligaron a concentrar en la región septentrional de la Península un elevado número de fuerzas militares, de al menos sie-

\footnotetext{
${ }^{1}$ Este trabajo se enmarca dentro del marco del proyecto de investigación: Campamentos romanos en la Península Ibérica: análisis arqueológico y arquitectónico, concedido por el MCYT (ref. BHA200203305), que se realiza desde el 1 de diciembre de 2002 bajo nuestra dirección. Una primera versión de este mismo artículo se encuentra actualmente en prensa dentro de la monografía: Villes et territoires dans le bassin du Douro à l'époque romaine, Bordeaux, 2004 (en prensa).
} 
te legiones, que desarrollaran varias campañas hasta terminar con la resistencia de los pueblos cántabros y astures. Los recintos de este periodo son todavía poco conocidos desde el punto de vista arqueológico, aunque se han realizado avances significativos (cf. Morillo, 2002: 72).

El final de la guerra y la subsiguiente partida de la mayor parte de las tropas hacia las fronteras septentrionales del Imperio inaugura claramente una etapa nueva en la relación entre el ejército romano y la Península. Es a partir de este momento cuando se fijan las bases de una política militar de ocupación territorial a largo plazo, puesta en práctica por Augusto y continuada por sus inmediatos sucesores (Morillo 1991: 177). La base de dicha actuación es la configuración de un exercitus hispanicus adscrito a la provincia Tarraconense, compuesto mayoritariamente por tres legiones seleccionadas entre las que habían participado en la guerra: la IIII Macedonica, la VI victrix y la $X$ gemina. De la permanencia de tres unidades como única guarnición estable en la Península queda constancia en un conocido pasaje de Estrabón (Geographica III, 4, 20), que menciona un legado al mando de dos legiones en el área astur, y un segundo legado con una única legión asentada en territorio cántabro. Durante esta fase posterior a la guerra, que se prolonga a grandes rasgos a lo largo de todo el periodo julio-claudio, se incrementan progresivamente los testimonios arqueológicos y epigráficos relativos a la actuación y la presencia del ejército romano en la Península. Es a partir de este momento cuando se crean una serie de bases estables para las tropas destacadas en el norte de la Península. Los establecimientos militares de Herrera de Pisuerga, Astorga y León son los primeros campamentos legionarios augusteos permanentes constatados arqueológicamente. Los tres ocupan emplazamientos geográficos y topográficos estratégicamente elegidos, en relación con las vías naturales de comunicación que enlazan el reborde noroccidental de la Meseta con las regiones costeras de Galicia y la Cornisa Cantábrica. Configuran un cordón protector al sur de la Cordillera Cantábrica, que hemos denominado limes sin frontera y que prefigura el esquema aplicado en las fronteras septentrionales del Imperio algunos años más tarde (Morillo, 1996: 81). El despliegue del ejército hispánico a lo largo de la vertiente meridional de la Cordillera Cantábrica y al este de los Montes de León se va a mantener hasta el final de la época julio-claudia y, a una escala menor, a lo largo del Imperio (Fig. 1).

Los campamentos del periodo augusteo y julio-claudio presentan especiales problemas de identificación. En su mayoría se encuentran bajo ciudades actuales, que han alterado las evidencias arqueológicas a veces de forma irrecuperable, lo que dificulta su reconocimiento arqueológico. Por otra parte, durante los reinados de Augusto y Tiberio, la técnica de castramentación aún se encuentra en periodo de conformación. Se emplean mayoritariamente estructuras temporales, realizadas en madera y la planta aún no está perfectamente regularizada. Por lo tanto, la identificación de estructuras constructivas propias de un asentamiento militar resulta muy difícil. No debemos olvidar además que las características geográficas y climáticas del norte de España, donde predominan los suelos rocosos y grandes os- 


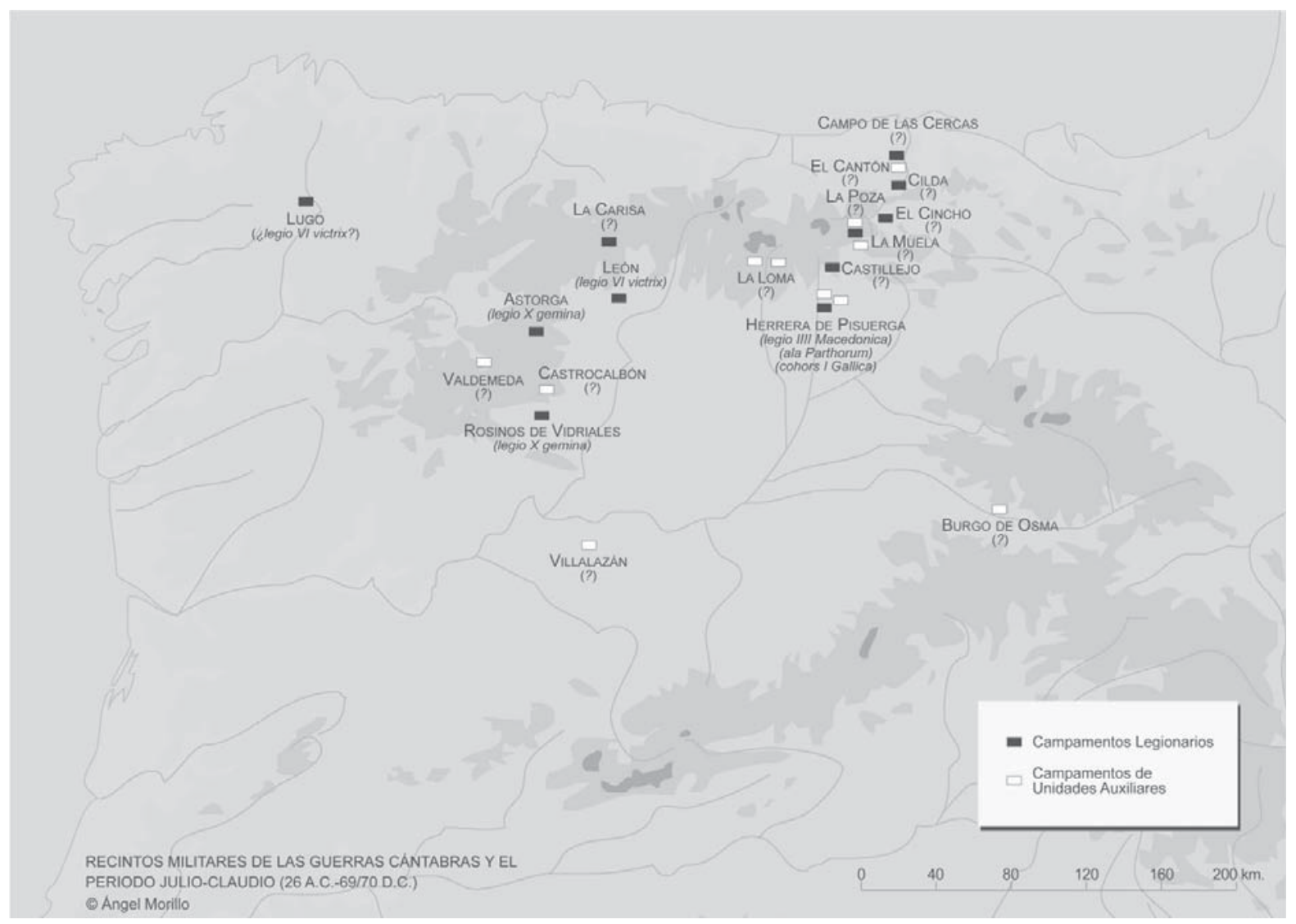

Fig. 1. Distribución de los campamentos de época julio-claudia en el cuadrante noroccidental de la península ibérica (según A. Morillo).

cilaciones térmicas, no facilita la conservación ni la identificación posterior de recintos militares (Morillo \& García Marcos, 2002: 780).

A la vista de estas dificultades, la identificación de recintos militares se ha hecho en muchas ocasiones tomando como base el análisis del registro arqueológico más antiguo de estos asentamientos, buscando elementos indiscutiblemente militares (TSI, Vogelkopflampen y lucernas de volutas de los tipos más antiguos, elementos metálicos típicos del ajuar militar, monedas de tipo militar como las emisiones con caetra, etc.) (Morillo, 1996: 79-80). En esta fase, la comparación con los materiales arqueológicos de los campamentos renanos más antiguos (Haltern, Oberaden, Vetera, etc.) ha tenido una importancia fundamental. Por lo general, la identificación de estructuras tiene lugar a partir de la definición previa del carácter militar de un asentamiento. El retraso en la investigación determina que conozcamos todavía muy poco sobre las plantas y distribución interna de los campamentos hispanos de este periodo.

El origen del desarrollo urbano en el norte de la Península se relaciona directamente con la presencia del ejército romano durante e inmediatamente después de las guerras cántabras. Los campamentos fueron los primeros asentamientos romanos en la región, que causaron una progresiva aculturación en la población in- 
dígena circundante Tan sólo algunas décadas más tarde, nuevos asentamientos civiles surgen sobre los antiguos campamentos legionarios estables. Sin embargo, la sustitución de las fuerzas militares por nuevos asentamientos civiles no fue completa y generalizada. Algunos establecimientos militares, como Astorga, dan lugar a un núcleo civil, mientras otros, como León, mantienen su carácter castrense hasta el final del Imperio. Posiblemente existió una política selectiva, que decide la finalidad de cada asentamiento en función de su situación y de los intereses concretos de la administración romana en cada caso (Morillo, 1998: 349-350). Presentaremos a continuación la problemática de los dos asentamientos que acabamos de mencionar, Astorga y León.

\section{EL CAMPAMENTO DE LA LEGIO X GEMINA EN ASTORGA}

Astorga, la antigua Asturica Augusta romana, está situada sobre un cerro en forma de espigón de $868 \mathrm{~m}$. de elevación, en el interfluvio de los ríos Jerga y Tuerto. Su emplazamiento se buscó en el límite Noroccidental de la Meseta Norte, al borde mismo de terrenos de naturaleza muy diversa: los Montes de León y Sierra de la Cabrera al oeste y Suroeste y las campiñas aluviales que rellenan el noroeste de la Cuenca del Duero al este. Esta posición estratégica la convierte en una encrucijada en las comunicaciones entre la Submeseta Norte y Galicia.

La ciudad de Asturica Augusta, capital del conventus Asturum, es mencionada por diversas fuentes clásicas, entre las que destacan Ptolomeo (Geog. II, 6, 35) y Plinio (NHIII, 28), que la define como «magnifica urbe». El Itinerario de Antonino la menciona en repetidas ocasiones como mansio de varias vías - XVII, XVIII, XIX, XX, XXVI, XXVII, XXXII, XXXIV— que confluían en la ciudad desde las principales ciudades hispanorromanas para, desde allí, dirigirse a otros enclaves del noroeste de Hispania, como Lucus Augusti o Bracara Augusta (Roldán 1975, passim). Por su parte, el Ravennate alude a la ciudad en uno de sus itinerarios (Ravennate, IV, 45: 355-375). A partir del siglo III d. C. vamos a encontrar referencias a la ciudad en Cipriano, Obispo de Cartago (c.200-c.258) (Epist. 67 tit), Hidacio (c.388-470) (Cont. chron. Hieron. 173, 186; Olymp. CCCVI, 130: XXI) e Isidoro, obispo de Sevilla (c.560-636) (Hist. Goth.21 y 16, en Mom. Germ. auct. antiq. XI, Chron. min. II, p. 279-280, además de en las Actas de diferentes Concilios, donde aparece la firma de los obispos asturicenses (González Alonso, 2002: passim).

Aunque ya en 1925 M. Gómez-Moreno, partiendo del análisis de las evidencias epigráficas, apuntaba que el origen de la posterior ciudad de Asturica Augusta debió ser un campamento de la legio X gemina (1925: 8-22), la mayoría de investigadores posteriores ha considerado Astorga como una ciudad de origen indígena, ya que en su trama urbana actual no se apreciaba nada que remitiera a un urbanismo ordenado (Luengo, 1956/61: 152-153; Pastor, 1976: 70-73; Palol, 1976: 270; García y Bellido et alii, 1987: 39). Aunque en los alrededores se conocen varios poblados de la Edad del Hierro, y aún anteriores, lo cierto es que hasta el mo- 
mento las numerosas excavaciones arqueológicas efectuadas dentro de la ciudad no han revelado ningún indicio que pueda considerarse como prerromano, por lo que debemos descartar que en su solar existiera nunca un establecimiento indígena.

No obstante, ya desde los años setenta, frente a los que postulaban un origen indígena para la ciudad, autores como Mañanes abogaban por un origen campamental (Mañanes, 1983: 12-13; 1983/84: 215). Asimismo, la mayoría de los historiadores que se han ocupado de las Guerras Cántabras sitúa en Astorga uno de los campamentos de la contienda (cf. Morillo, 1991: 163-164). El argumento fundamental de esta hipótesis es un pasaje de Floro citado de forma reiterada y casi automática al hablar del supuesto origen campamental de algunas ciudades del norte peninsular: «(Augusto)...quien recelando del amparo ofrecido por los montes en que se refugiaban (los indígenas), les ordenó habitar y establecerse en los campamentos situados en la llanura. Allí había el consejo del pueblo, y aquel poblado recibía los honores de capital» (Epitome rei militari II, 33, 59-60). Debido a la posición concreta que ocupa este pasaje en la narración de Floro, inmediatamente después de la campaña contra los astures que culmina con la toma de Lancia, la investigación ha considerado que hace referencia a Asturica Augusta, más tarde principal ciudad astur y capital del convento jurídico (Schulten, 1943: 154; Mañanes, 1976: 77-78; Le Roux, 1982: 75).

Ya hemos señalado recientemente (Fernández Ochoa \& Morillo, 1999: 3940) que la exégesis textual parece no haber reparado que entre la derrota astur en Lancia y el pasaje que hemos reproducido anteriormente, Floro realiza una consideración general sobre el final de la guerra, que se aplica al conjunto de los pueblos derrotados, aunque más tarde vuelva a referirse en particular a los astures en relación con la explotación de los recursos auríferos (Epit. II, 33, 60). De cualquier forma, no podemos considerar esta cita como una prueba directa del carácter militar de Astorga durante las guerras de conquista, tal y como algunos autores han propuesto.

La hipótesis sobre el origen militar de la ciudad de Asturica se fundamentaba asimismo en el hallazgo de varios epígrafes funerarios de soldados de la legio $X$ gemina reutilizados en la obra de la muralla bajoimperial de la ciudad (Tranoy, 1981: 139-140). La transformación ulterior del campamento en capital del convento jurídico pudo actuar como polo de atracción regional para veteranos licenciados del ejército, por lo que no podemos distinguir si estos testimonios funerarios pertenecen a soldados en activo o a dichos veteranos (Morillo \& García Marcos, 2000: 597). Pero hasta hace pocos años faltaban argumentos auténticamente arqueológicos que probaran el origen militar de Asturica Augusta.

Durante los últimos quince años este panorama se ha visto alterado de forma radical. Las numerosas excavaciones arqueológicas llevadas a cabo en esta localidad han puesto de manifiesto un horizonte arqueológico en los niveles inferiores del yacimiento muy semejante al de otros yacimientos como Herrera de Pi- 
suerga y León, que podemos considerar como indudablemente militar (Morillo \& García Marcos, 2000: 598). Dicho registro arqueológico se ha detectado en los niveles inferiores de determinados sectores - ( $v$. Morillo, 1999: passim; Morillo et alii, 2005: 142-144; Morillo \& García Marcos, 2006c y 2006d: e. p). Corresponde a un estrato de relleno $o$ aterrazamiento procedente de los antiguos vertederos campamentales, caracterizado por la coloración ocre-verdosa de la tierra, que se extiende por toda la superficie ocupada más tarde por la ciudad. Parece corresponder a una gran remodelación urbanística que, a nuestro juicio, se encuentra relacionada con la amortización de las estructuras campamentales iniciales, de las que apenas habrían quedado restos, y la transformación del antiguo asentamiento castrense en el núcleo civil de Asturica Augusta (Morillo, 1999: 317; Morillo \& García Marcos, 2001: 598-599). Materiales pertenecientes asimismo a esta primera fase militar del asentamiento romano han aparecido en posición secundaria en niveles arqueológicos datados a lo largo de todo el siglo I d. C. (Fig. 2).

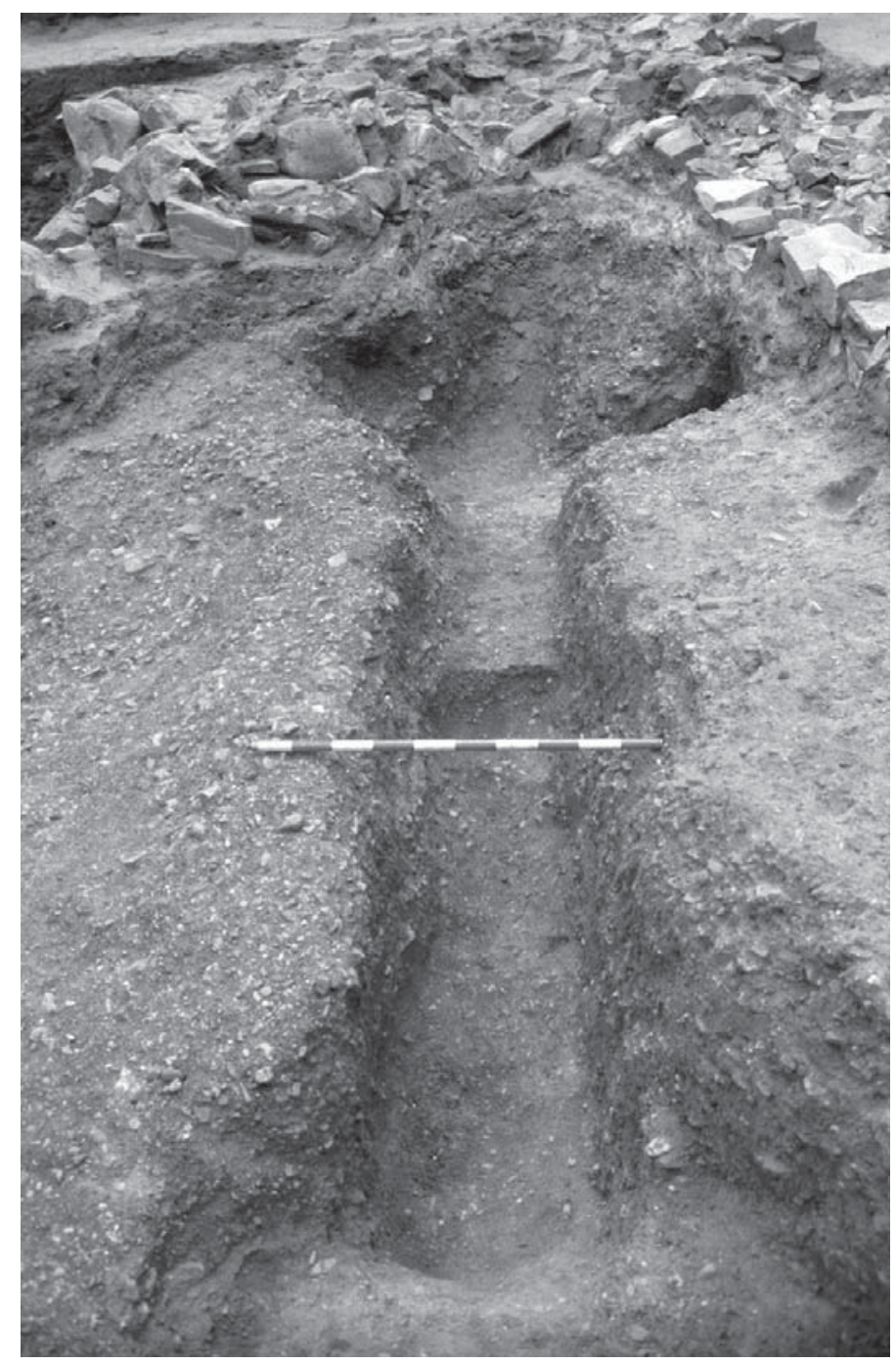

Fig. 2. Estructuras negativas destinadas a albergar construcciones de madera pertenecientes al campamento de la legio X gemina en Astorga (Foto: V. García Marcos). 
Los contextos militares están definidos por la presencia de recipientes de terra sigillata itálica atribuibles a P. Cornelivs, Memmivs, Ateivs, Favor, Murranvs o Verecvndvs, así como por ánforas itálicas y béticas, lucernas de los tipos Dressel 4, Loeschcke IA y Loeschcke III, y numerario augusteo de cecas hispanorromanas y acuñaciones del Noroeste (cf. Morillo et alii, 2005: 142-144). Las características de los restos materiales adscribibles al asentamiento militar permiten remontar su fundación a un momento anterior al cambio de Era, en torno al 15/10 a. C., posterior en todo caso a las Guerras Cántabras (Morillo, 1999: 317-318 y 335; Morillo \& García Marcos, 2000: 598).

Las excavaciones desarrolladas en la llamada Casa del pavimento de opus signinum y en el sector de Puerta Obispo, revelaron asimismo restos correspondientes a estructuras constructivas negativas, practicadas sobre el nivel natural del terreno, a modo de trincheras o zanjas de cimentación, destinadas a albergar durmientes en madera para cimentar construcciones sustentadas mediante postes, cuyas huellas han quedado marcadas sobre el terreno. Dichas estructuras responden a modelos propios de la arquitectura militar romana en madera (Morillo \& García Marcos, 2000: 598) y quedaron selladas mediante el nivel de relleno o aterrazamiento donde se concentra la mayor parte de los materiales de la fase militar. El reciente hallazgo de un doble foso del tipo fossae fastigatae, de sección en « $\bigvee$ », perteneciente sin lugar a duda al sistema defensivo del campamento, constituye un argumento decisivo respecto al carácter militar del primitivo asentamiento de Astorga (González Fernández, 1996: 85-90).

Un documento epigráfico que hemos dado a conocer recientemente apunta a la legio X gemina como la unidad alojada en este campamento (García Marcos \& Vidal, 1995: 115; Morillo \& García Marcos, 2000: 598-599). En las excavaciones realizadas en un solar cercano a la muralla bajoimperial se encontraron dos grandes bloques de granito desplazados de su posición original y reutilizados en una obra posterior ${ }^{2}$. Su importancia radica en que ambos presentaban la inscripción L.X.G. grabada en grandes letras capitales cuadradas en una de sus caras mayores. La abreviatura L.X.G. está perfectamente atestiguada para dicha unidad en epígrafes contemporáneos ( $v$. Roldán, 1974: 451-454). Asimismo, conocemos un bloque de piedra de parecidas dimensiones y con la misma inscripción hallado en Carnuntum, localidad donde se estaciona la legio X gemina tras su partida de la Península (CIL III, 11245).

Al calor de este documento epigráfico, las lápidas de soldados de dicha unidad encontradas en Astorga (Mañanes, 1982: 40-45, n² 21-25) adquieren un mayor vaIor testimonial y corroboran el establecimiento de dicho cuerpo en Astorga.

La duración del recinto castrense establecido en Astorga parece ser corta. A juzgar por el registro arqueológico, hacia el 15/20 d. C., esto es, a comienzos del reinado de Tiberio, se acomete una gran remodelación en el asentamiento, coin-

2 Uno de ellos presenta una anchura de 0,72 m., una altura de 0,56 m. y una profundidad de 0, 58 $\mathrm{m}$. El segundo es de un tamaño ligeramente mayor, de 0,72 m. de altura, 0,63 m. de anchura y 0,64 m. de profundidad. 
cidente con su transformación en ciudad y capital del conuentus, transformación que sin duda está en relación con el inicio de las explotaciones auríferas a gran escala en la región (Morillo, 1999: 335; Morillo \& García Marcos, 2000: 598). Hacia esta fecha se detecta una gran remodelación urbanística con potentes niveles de aterrazamiento y relleno llevada a cabo en el solar ocupado más tarde por la ciudad. Sin embargo, pensamos que dicha transformación no se lleva a cabo al mismo tiempo en todo el yacimiento. A nuestro juicio, ésta constituye la única explicación convincente sobre la amortización de los fosos campamentales con materiales de época claudia, tal y como se desprende de su análisis arqueológico (Morillo, 1999: 335). De cualquier manera, la transformación del campamento en asentamiento de carácter civil se acometió en los inicios del reinado de Tiberio ${ }^{3}$.

La cronología del asentamiento de la Legión X Gémina en el solar de la posterior ciudad de Asturica Augusta se ajusta en esencia al vacío documental que parece detectarse en el campamento de Rosinos de Vidriales entre el final de las guerras cántabras y el periodo tardoaugusteo, ya que el registro arqueológico correspondiente al periodo más antiguo de dicho campamento permanece por el momento inédito. Aunque recientemente $\mathrm{S}$. Carretero y $\mathrm{M}^{\mathrm{a}} \mathrm{V}$. Romero Carnicero retrasan su fundación hasta el 20/15 a. C., una vez terminada la contienda (1996: $10)$, estos mismos autores ya señalan que el patrón material más antiguo presenta materiales en su mayoría posteriores al cambio de Era y su mayor concentración arranca del reinado de Tiberio, lo que nos ha llevado a plantear, a modo de hipótesis, que la fundación del campamento de Rosinos se retrasara hasta un momento tardoaugusteo-tiberiano (Morillo, 2002: 84). Es posible plantear que la Legión X, o al menos parte de ésta, estuviera asentada en Astorga antes de su traslado definitivo a su campamento estable en Rosinos de Vidriales, pocos kilómetros más al sur. En cualquier caso debemos tomar esta hipótesis con cierta cautela en tanto los datos arqueológicos o epigráficos no suministren una información más detallada, ya que existe la posibilidad de que ambos campamentos adscritos a la legio $X$ gemina pudieran coexistir durante algunos años.

\section{LOS CAMPAMENTOS ROMANOS DE LEÓN}

\section{El origen del asentamiento militar romano de León: los campamentos de la legio VI victrix}

La ciudad de León se asienta en un suave altozano ubicado en el interfluvio constituido entre los ríos Bernesga y Torío, rellano ligeramente dominante sobre sus cauces, que parece corresponder a la última terraza originada por su dinámica

${ }^{3}$ No obstante, siguen planteándose ciertas dudas sobre la cronología de amortización del foso campamental recientemente defendida por González (1996), ya que al menos los materiales lucernarios recuperados son al menos una o dos décadas posteriores al resto de materiales procedentes del primer horizonte militar del yacimiento documentado en otros lugares, tal y como apuntamos en su día (Morillo, 1999: 335). 
fluvial. En efecto, el lugar donde se asienta la ciudad, auténtica encrucijada entre la Meseta y la Montaña Central leonesa, ofrecía unas condiciones topográficas y espaciales de un valor estratégico que no pasó desapercibido a los romanos. Estas características son coincidentes con las de los asentamientos militares augusteos de Astorga y Herrera de Pisuerga, lo que indica que la morfología del lugar, junto a su valoración geoestratégica, fueron determinantes en su elección por parte del estado romano (Morillo, 1996: 80).

Este enclave es mencionado por Ptolomeo como lugar de emplazamiento de la legio VII gemina (Geographica II, 6, 28). En el Itinerario de Antonino aparece como punto de llegada de la vía I, de Italia in Hispanias (387, 7 y 395, 4). Asimismo, la Notitia Dignitatum (XLII, I, 26) ubica en Legione a la Legión VII Gémina en época bajoimperial. La Tabla I del llamado Itinerario del Barro, de problemática autenticidad (Roldán, 1972/73: 228-229; Arias, 1987: 1-82), menciona el emplazamiento de la legio VII gemina como punto de partida de una vía que termina en la costa cantábrica, concretamente en Portus Blendium ${ }^{4}$.

Si bien ya desde el siglo XVIII la historiografía venía aceptando sin ningún género de duda la presencia de la legio VII gemina en la ciudad de León, no fue hasta los trabajos de García y Bellido durante los años sesenta (1970: 569-599) cuando el asentamiento de la mencionada legión en el solar leonés quedó concretado en torno a los años 74/75 d. C. (Fig. 3). La fundación de dicha unidad habría tenido lugar algunos años antes, concretamente en el año $68 \mathrm{~d}$. C., con motivo del levantamiento de Galba en la provincia Tarraconense contra el gobierno de Nerón (García y Bellido, 1970b: 303-329). La legio VII gemina, de la que deriva incluso el nombre de la ciudad de León, permanecerá de guarnición en este mismo lugar hasta el final del Imperio.

No obstante, tanto García y Bellido (1961: 125) $)^{5}$ como, posteriormente, Alföldy (1969: 115) y Le Roux (1982: 106), consideraron la posibilidad de un asentamiento legionario anterior. Esta argumentación se basaba fundamentalmente en el texto de dos inscripciones. La primera, hallada en Rímini y dedicada a un primipilus llamado Marcus Vettius Valens, hace referencia, por primera y única vez, a la legio VI victrix participando en la represión de una revuelta de los astures durante el reinado de Nerón (CIL XI, 395; Roldán, 1974: 450-451, n 543). El segundo de los textos, hoy perdido, fue hallado en la fábrica de la muralla leonesa en la zona de Puerta Obispo. Atribuido al legado L. Pupius Praesens (CIL II, 2666; Diego, 1986: núm. 70), en éste aparece mencionada una legión terminada en -trix, por lo que únicamente podría tratarse de la I adiutrix, o, con mucha más probabilidad, la VI victrix. Para reafirmar esta opinión, Le Roux (1982: 106) se apoya también en una serie de materiales cerámicos datados en época claudia que fueron hallados

\footnotetext{
4 No vamos a mencionar aquí la amplia bibliografía existente sobre este documento epigráfico, que ya hemos recogido en otro lugar (Morillo, 2000: 615, nota 41).

5 Si bien en un primer momento García y Bellido (1961: 125) abogó por la presencia en el solar leonés de la legio VI victrix, posteriormente se inclinó por la legio X gemina (García y Bellido, 1966: 22).
} 


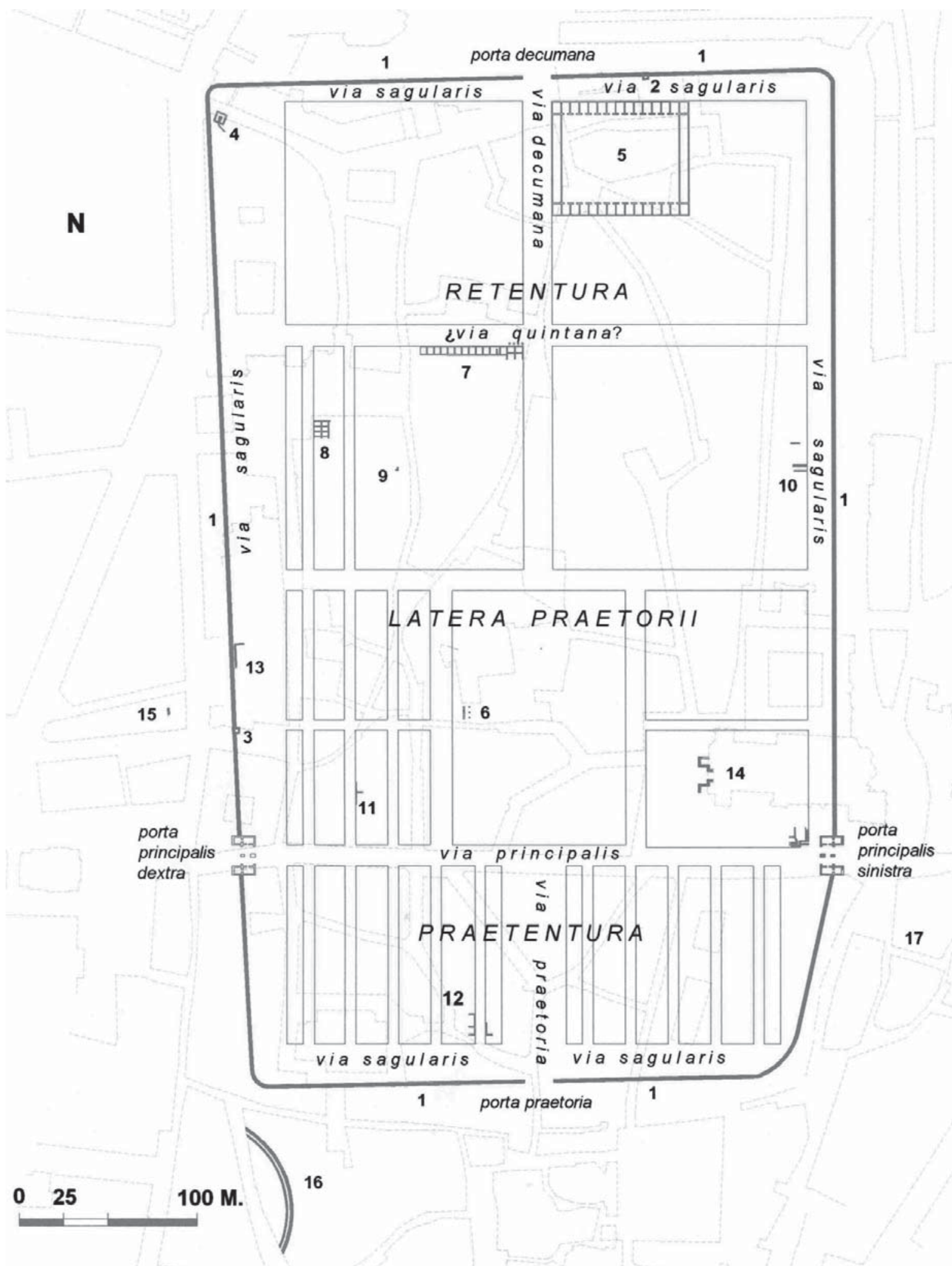

Fig. 3. Planta del trazado hipotético del campamento de la legio VII gemina en León, con indicación de los restos arqueológicos exhumados (según V. García Marcos). 
por García y Bellido en sus excavaciones de los años 1961 y 1967 en la Huerta de San Isidoro (1970: 580-581), además de la Tabla I del Itinerario de Barro aunque, como hemos señalado, este documento plantea ciertos problemas de autenticidad.

A los materiales de cronología temprana cuya presencia apunta, de forma genérica, García y Bellido en sus excavaciones de León, habría que unir las numerosas piezas, especialmente cerámicas, aparecidas en las obras de construcción, entre 1970 y 1972, del aparcamiento subterráneo de la plaza de San Marcelo, espacio extramuros próximo al lugar que en su día debió de ocupar la porta principalis dextra del campamento de la legio VII gemina (García Marcos, 2002: 189). Como resultado de los trabajos se extrajo un gran volumen de tierras que se depositaron en un vertedero municipal situado en las afueras de la ciudad, del que se recuperaron años más tarde numerosos materiales arqueológicos. Algunos de ellos han sido ya objeto de estudio, en especial la terra sigillata hispánica (García Marcos, 1986 y 1989-1990: 89-114) y las lucernas (Morillo, 1999: passim). No obstante, la mayor parte permanecen aún inéditos. Entre ellos destaca una importante cantidad de terra sigillata itálica y gálica. Si en un primer momento se creyó que esta zona había servido como vertedero del asentamiento romano, excavaciones ejecutadas recientemente en el Edificio Pallarés y en la Casa Botines, ubicados en la misma zona, permiten afirmar que, además, hubo un uso ocupacional representado por diversas estructuras de habitación, las más antiguas datables a finales del siglo । a. C. y comienzos de la siguiente centuria (Miguel \& García Marcos, 1994: 175-206).

Entre los abundantes materiales exhumados en esta zona, cuya cronología abarca un margen temporal situado entre finales del mandato de Augusto o comienzos del de Tiberio y el reinado de Claudio, se ha identificado recientemente una producción local de terra sigillata de tradición itálica, cuyos recipientes están firmados por un alfarero llamado $C$. Licinius Maximus, inédito hasta el momento y que abastecía con sus productos a la unidad militar establecida en León durante el periodo augusteo (Morillo \& García Marcos, 2001: 151-154; García Marcos, 2005).

Con todo, ha sido la reciente excavación de un extenso solar adosado al intradós del lienzo norte de la muralla de cubos tardorromana, a escasa distancia de Puerta Castillo — la porta decumana del campamento de la legio VII- la que de forma más explícita nos ha permitido ilustrar el inicio de la presencia romana en la ciudad de León. A partir de los datos aquí extraídos se ha podido reconocer la presencia de dos recintos campamentales anteriores al de la legio VII, ocupando, sin solución de continuidad, el marco temporal existente entre los años finales del siglo I a. C. y la época flavia. El primer recinto debió ser fundado en época augustea, concretamente hacia el cambio de Era. Dicho campamento constaba de un agger con foso de perfil en "V $\mathrm{V}$ y vallum del tipo box rampart, formado por dos paramentos de madera con postes verticales de refuerzo y relleno interno de grava y arcilla. Al exterior de las defensas se desarrollaba un pavimento viario de unos 7 metros de anchura, pavimentado con pequeñas piedras. También han llegado 
hasta nosotros algunos restos de construcciones interiores de carácter indeterminado con suelos de madera y tabiques construidos con carrizo y revestidos con barro (García Marcos, 2002: 172; García Marcos \& Morillo, 2002: 793).

Durante los años finales del reinado de Augusto o comienzos del de Tiberio (10/15 d. C.), coincidiendo con los cambios en la política militar aplicada en Hispania (Morillo, 2002: 83), el primer recinto campamental de León sufre profundas transformaciones. El agger anterior va a ser desmontado y sobre él se construye uno nuevo. En esta ocasión, el terraplén estará construido mediante bloques regulares de tierra y césped, denominados tapines - caespites-, dispuestos formando dos paredes paralelas, con su interior relleno con tierra mezclada con cantos de río hasta alcanzar una anchura total de aproximadamente 4 metros. Este es el tipo de agger denominado «de doble revestimiento» (Fig. 4). La cara externa de este terraplén, así como el fosos o fosos que sin duda debió tener, fueron arrasados durante la construcción de la muralla del campamento de la legio VII gemina en época flavia, que se superpone casi exactamente sobre las defensas del campamento anterior. El perímetro interno de la fortificación se ve recorrido por un intervallum ocupado íntegramente por la via sagularis. A continuación se levanta un barracón de tropa (centuria) paralelo a las defensas del nuevo recinto, cuyo zócalo está realizado en piedra. Los ambientes interiores que constituían los cuatro con-

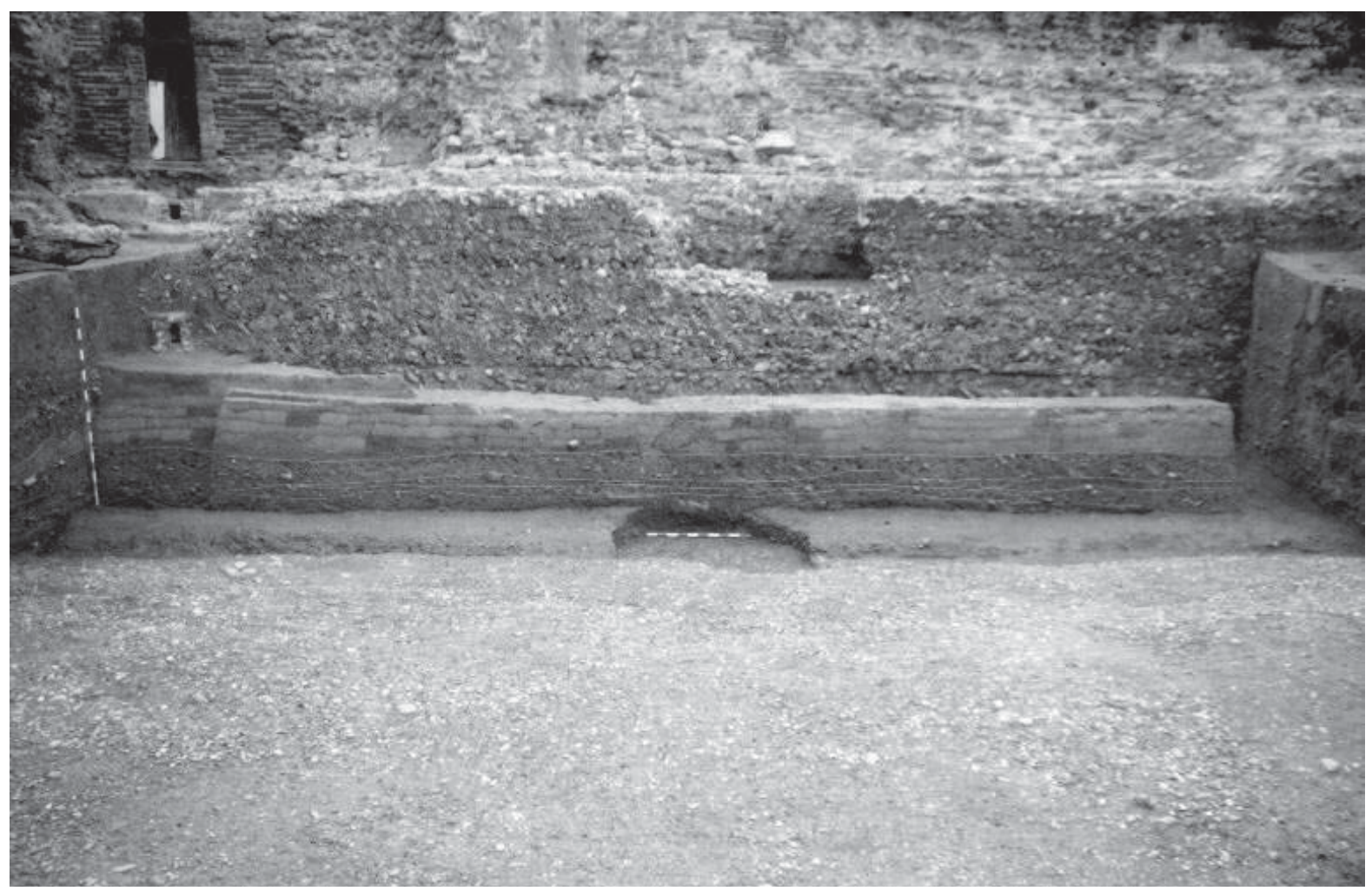

Fig. 4. Vallum del campamento julio-claudio (León II) hallado en el transcurso de la intervención practicada en el sector norte del actual recinto murado (calle de Santa Marina). Inmediatamente detrás se observa la cara interna del primer muro defensivo levantado por la legio VII gemina (Foto: V. García Marcos). 
tubernia documentados se encuentran muy deformadas porque sobre ellas se construyó una nueva estructura perteneciente a la legio VII gemina (García Marcos, 2002: 178).

Aunque por el momento los hallazgos de Puerta Castillo representan el ejemplo más claro de esta segunda fase campamental, diversas excavaciones practicadas en el interior del recinto amurallado — plazas del Vizconde, Santo Martino y Conde Luna, calles Serranos, San Pelayo y Cardenal Landázuri-, han ido corroborando reiteradamente la continuidad de la ocupación romana en León durante el periodo julio-claudio (Campomanes et alii, 2002: passim). Sin embargo, como sucedía con la etapa anterior, los restos constructivos conservados son fragmentarios y dispersos, lo que en muchos casos hace difícil aventurar una adscripción clara sobre su funcionalidad.

Al pie del costado meridional de lo que posteriormente será el recinto fortificado de la legio VII, extramuros pero muy próximo al lugar ocupado por la porta praetoria, existió un complejo artesanal dedicado a funciones metalúrgicas, en concreto al tratamiento del hierro, tal y como parecen indicar las características que presentaban los diversos ambientes de trabajo, así como los materiales a ellos asociados. Su período de actividad parece ser relativamente corto, abarcando el segundo tercio del siglo I d. C. (Campomanes, 1998/99: 269-279; Aurrecoechea, 2006: e. p.).

También extramuros, al sureste del recinto campamental, en la zona denominada polígono de La Palomera, se ha localizado una gran construcción rectangular - $35 \mathrm{~m}$. de largo y 12 de ancho- definida por muros de opus caementicium encofrados por medio de tablones de madera y pavimentos de argamasa. Los materiales asociados a los niveles que aparecieron amortizando su interior muestran que dejó de usarse hacia mediados de la centuria, prolongándose los vertidos hasta la época flavia (Vidal \& García Marcos, 1996: 151; Morillo, 1999: 37; Martín Hernández, 2006: e. p.). Su función sigue siendo problemática, si bien todos los indicios apuntan a su uso como depósito de agua. Con posterioridad, el extremo meridional de esta construcción se reacondicionó, probablemente como calero, cerrándose con un murete de mampostería perpendicular a los lados mayores y recibiendo una solera con tegulae invertidas, no presentando ninguna de ellas sello.

Sobre los campamentos julio-claudios de León se plantean en el estado actual de la investigación numerosos interrogantes. La dispersión de los hallazgos parece dibujar un contorno bastante similar al que más tarde poseyó el de la legio VII, circunstancia en la que debieron de incidir fuertemente las características topográficas de lugar. Aunque su contorno exacto no ha podido ser definido, las recientes excavaciones desarrolladas en la plaza del Conde Luna han permitido constatar el hallazgo del agger correspondiente al lienzo meridional del segundo recinto, también en este caso a escasa distancia de las defensas de la legio VII gemina. Este hecho permite aclarar una de las incógnitas que todavía subsistían so- 
bre dicho campamento, como era la de su superficie, sin lugar a dudas asimilable al campamento posterior de la legio VII gemina, es decir, de unas 20 ha. y, por lo tanto, legionario.

Por lo que se refiere a la unidad ocupante de ambos recintos, diversos testimonios apuntan a la legio VI victrix. Entre ellos destaca la lápida hoy perdida a la que hemos aludido anteriormente (Alföldy, 1969: 115), varias monedas con resello de dicha unidad, una de ellas procedente de las excavaciones desarrolladas en la plaza del Vizconde de la capital leonesa (García de Figuerola \& González Alonso, 1998/99 y 1999; Morillo, 1999c: 78-79) y un fragmento de lucerna con una peculiar marca realizada con grandes letras capitales cuadradas y desgraciadamente incompleta, en la que hemos leído L.V.¿l? (Morillo, 1999: 296-297, n. ํ 40, fig. 170). Dicha abreviatura está perfectamente testimoniada en Hispania tanto en epigrafía como en numismática para aludir a dicha unidad militar. A tenor de estas evidencias debemos aceptar que la legio VI victrix estuvo estacionada en León al menos entre el cambio de Era y su partida definitiva de la península ibérica en el 69/70 d. C. (Morillo \& García Marcos, 2000: 600).

\section{El campamento altoimperial de la legio VII gemina}

Tras la partida de la legio X gemina hacia Carnuntum, en Pannonia, durante el año 63 d. C., el ejército hispánico quedó reducido a una única legión, la VI victrix, acantonada en León, acompañada, según Suetonio (Galba, X, 2), por dos alae y tres cohortes, que debieron estar adscritas a la unidad legionaria. La Legión VI Victrix participó activamente en la sublevación del año 68 de Galba contra Nerón y en el levantamiento en una nueva unidad compuesta por hispanos en Clunia, la VII «Galbiana», más tarde denominada gemina (García y Bellido, 1970b: 321-325). Esta nueva unidad respondía a la necesidad de Galba de contar con más tropas en su previsible lucha contra el último de los julio-claudios y recibió el numeral VII, correlativo al de la única unidad presente en aquel momento en la Península, la VI victrix, su legión matriz. La Legión VII creada por Galba constituye de hecho el embrión de la futura VII gemina ${ }^{6}$. Gracias a dos de las lápidas descubiertas en Villalís ${ }^{7}$ conocemos la fecha exacta en la que la legio VII recibió sus insignias, lo que acaeció el 10 de junio del año 68 d. C. (CIL II, 2552 y 2554; Diego, 1986: 51-52, n. ${ }^{\circ}$ 33 y $\left.53-55, n^{\circ} 35\right)$.

A partir de este año 68 se inicia un periodo muy turbulento en la historia de Roma. Durante algo más de un año sucesivos pretendientes luchan por el trono imperial, que terminará por asegurarse Vespasiano. A pesar de los numerosos mo-

\footnotetext{
6 Entre la abundante bibliografía que hace alusión a la creación e historia de la legio VII podemos citar los trabajos de Ritterling (1925: col. 1630-1641), García y Bellido (1970: 303-328), Roldán (1974: 201204), Tranoy (1981: 171-173) Le Roux (1982: 151-153), y Abascal (1986: 317-328).

7 A ellas habría que añadir una tercera, muy fragmentada, procedente de la ciudad de León y dada a conocer por García y Bellido (1970: 324).
} 
vimientos de tropas que se registran en apoyo de uno u otro candidato, el exercitus hispanicus no sólo no se reduce, sino que se engrosa con dos nuevas unidades: la $X$ gemina, que regresa a la Península desde Carnuntum, y la I adiutrix. La nueva concentración de unidades en una región alejada de los principales conflictos debemos entenderla como una afirmación de la importancia estratégica de Hispania. Aunque en algún momento dichas unidades desempeñaran un papel estrictamente militar, como la defensa de la Bética encargada a la Legión X Gémina por Otón ${ }^{8}$, el principal cometido asignado a estas legiones debía ser el control de la producción aurífera del noroeste peninsular, que debió funcionar durante estos años a pleno rendimiento. Sobre dicho recurso debieron de cimentarse buena parte de las ambiciones de los sucesivos pretendientes a la púrpura imperial (Morillo, 2002: 87-88).

Tan sólo en el invierno del 69/70 las tres legiones dislocadas en Hispania abandonan definitivamente la Península para hacer frente a la grave situación creada en la frontera del Rin por la revuelta bátava de lulius Civilis.

Por lo que se refiere a la legio VII Galbiana, en octubre del 68 d. C. ya está operando en Roma, para posteriormente ser destinada al limes danubiano. Tras la muerte de Galba toma partido por Otón, regresando de nuevo a Italia. Con Vitelio retorna brevemente al Danubio, desde donde apoya a Vespasiano, lo que la llevará a participar en la segunda batalla de Bedriacum (cerca de la actual Cremona), sufriendo tan graves pérdidas que le fueron asignados efectivos procedentes de otra legión indeterminada, portando a partir de este momento el epíteto de gemina (doble, acoplada) (Tácito, Historiae III, 22). En el 73/74 d. C. se encuentra en la Germania Superior, donde aparece ya con los epítetos gemina y felix (CIL VI, 3538; XIII, 5033 y 12167, 1-8) ${ }^{9}$.

La vuelta a Hispania de la legio VII debió de producirse a finales del año $74 \mathrm{~d}$. C. ${ }^{10}$, aunque no va a ser hasta el 79 cuando aparezcan las primeras referencias a su estancia en sendas inscripciones de Aquae Flaviae y Cornoces (Orense) (CIL II, 2477 y IRG IV, 92, respectivamente). Dicha unidad escoge para asentarse la misma región que sus predecesoras, e incluso el mismo lugar físico que la legio $\mathrm{VI}$, ocupando un recinto que contaba ya con una larga tradición castrense. Esto indicaría bien a las claras la continuidad de los objetivos respecto al periodo anterior

8 Tácito, Historiae II, 58.

9 Sobre el apelativo de gemina v. Morillo, 2006b: e. p.

${ }^{10}$ García y Bellido sostiene que antes de la llegada de la totalidad de la legio VII a la Península, algunas de sus vexillationes pudieron estar ya acantonadas en León construyendo el recinto que más tarde iba a ocupar aquélla. Esta opinión se fundamenta en el hallazgo en la ciudad de varias marcas latericias en las que la legión aparece exclusivamente con el epíteto gemina, sin el felix que obtendría en o antes del año 74 d. C. (1970: 589 y 591). La arqueología parece poder confirmar este análisis, no tanto en el sentido de la presencia de tropas específicamente de la legio VII, hecho bastante probable, como en el de la falta de un paréntesis temporal entre el abandono del campamento de la etapa julio-claudia y el levantamiento del de la legio VII. Sin embargo, nuestra opinión es que los destacamentos de ésta llegarían con posterioridad al otoño del 68, fecha en la que parece recibir el apelativo de gemina, y más probablemente en el 69-70, momento en el que la legio VI parte definitivamente de Hispania hacia el Rin. 
(Morillo, 1996: 80). A partir de este momento su base permanente de operaciones a lo largo de todo el Imperio será León, la cual no abandonará sino en contadas ocasiones.

Los móviles que explican esta elección geográfica están estrechamente vinculados a la creciente importancia que el noroeste de Hispania fue adquiriendo a lo largo de todo el siglo I d. C. y, en particular, a partir de los Flavios. Aunque el beneficio de los recursos mineros, especialmente los auríferos, había comenzado décadas antes, va a ser a partir del último cuarto del siglo I d. C. cuando comience su explotación a gran escala (Domergue, 1986: 33; Sánchez-Palencia \& FernándezPosse, 1985: 322-324), situación que hará necesaria la presencia de un importante contingente de tropas, cuya función sería tanto la construcción, como la vigilancia, mantenimiento y control de las vías que daban salida al preciado metal, así como la aportación del apoyo técnico necesario para facilitar la importante infraestructura que precisaban las explotaciones mineras y su administración (Domergue, 1970: 272-275; 1986: 36-38; Abascal, 1986: 323; Fernández-Posse \& Sánchez-Palencia, 1988: 152-176 y 218-222). La importancia que la administración romana otorgaba a la explotación de los recursos auríferos se plasmó en la creación de la Vía XVIII en época flavia, también conocida como Via Nova (Tranoy, 1981: 215), en cuyo trazado es seguro que participarían contingentes de la legión ${ }^{11}$.

Legio va a estar perfectamente integrada en la tupida red de calzadas que unía los tres conventos noroccidentales - Asturum, Lucensis y Bracarensis-, además de enlazar con Tarraco a través de la Meseta Norte y el valle del Ebro, y con Emerita Augusta por el sur. También estuvo conectada con la Asturia Transmontana a través de Lucus Asturum (Lugo de Llanera, cerca de Oviedo), y con la costa cántabra en Portus Blendium (Suances, Santander) (Tranoy, 1981: 206-220; Rabanal, 1988; Fernández Ochoa, 1995: 99-102; Fernández Ochoa \& Morillo, 1999: 89-92).

Las numerosas excavaciones llevadas a cabo durante los últimos quince años en el casco urbano han permitido conocer numerosos aspectos del asentamiento militar de la legio VII en León. El principal testimonio arqueológico del campamento edificado por dicha unidad militar junto a la confluencia del Bernesga y el Torío sigue siendo el magnífico perímetro defensivo de planta rectangular con esquinas oblongas, que sigue el modelo campamental canónico. Las excavaciones desarrolladas durante los años sesenta por A. García y Bellido revelaron que el recinto amurallado, reforzado exteriormente con torres semicirculares, está constituido en realidad por dos lienzos adosados, edificados con técnicas bien distintas y erigidos en diferentes momentos (García y Bellido, 1970: 572-575; v. tb. Campomanes, 1997: 127-148 y Durán Cabello, 2006: e. p.).

Las intervenciones practicadas en un gran solar ubicado en la zona de Santa Marina, junto al interior del lienzo septentrional de la muralla, han contribuido a re-

11 De su actividad constructora tenemos testimonio por la mencionada inscripción de Aquae Flaviae, en donde la legio VII colabora en la realización de un puente. 
solver muchos de los interrogantes que planteaba este primer recinto defensivo (García Marcos, 2002: 186-187; García Marcos \& Morillo, 2000/01: 109; Morillo \& García Marcos, 2003b: 280-282). Primeramente se practicó una trinchera cuyo trazado motivó el desmantelamiento de la mitad exterior del vallum del campamento precedente, perteneciente a la legio VI y datado en época julio-claudia. En el interior de esta fosa fundacional se construyó una cimentación de cantos rodados de cuarcita. El lienzo superior presenta un paramento externo de opus vittatum compuesto por sillarejos de arenisca con juntas realzadas por un excelente encintado de argamasa (García y Bellido, 1970: 573). El resto del muro, hasta alcanzar los 1,80-2 m. de anchura (en torno a 6 pies romanos), se levantó en opus caementicium de excelente calidad. Dicho paramento no se verifica en la cara interna del lienzo, donde se construyó un terraplén interno adosado al núcleo pétreo, como ya había supuesto Campomanes (1997: 135), que aprovechó parte del vallum del campamento anterior.

Durante los últimos años se ha constatado la existencia de al menos tres torres interiores de planta rectangular, elementos comunes en los campamentos del periodo altoimperial (García Marcos \& Morillo, 2000/01: 110-111). Aún no tenemos constancia arqueológica de torres en los ángulos, aunque es casi seguro que el campamento altoimperial de León también las tuviese. La fortificación del campamento de la legio VII gemina se completaría, como es usual, con la presencia de uno o más fosos que circunvalasen el exterior del perímetro murado, de los que no quedan evidencia alguna debido al levantamiento de la muralla tardorromana.

En efecto, a finales del siglo III o comienzos del IV se construye un segundo muro que envuelve al anterior por su cara externa con un aparejo de piedras mal labradas de mucha peor calidad, de unos $5,25 \mathrm{~m}$. de anchura y núcleo interno de hormigón, reforzado con torres semicirculares de 8, $25 \mathrm{~m}$. de diámetro dispuestas cada 15 m. (García y Bellido, 1970: 571-575). En dicha obra se emplearon abundantes materiales epigráficos reutilizados. La obra de la muralla presenta un espesor total de $7 \mathrm{~m}$. y una altura conservada de $5,5 \mathrm{~m}$.

Los investigadores han formulado diversas hipótesis sobre el momento de construcción de estos dos recintos adosados. Para Gómez-Moreno la muralla interior sería la estrictamente romana, mientras que el lienzo externo con los cubos semicirculares sería obra medieval (1925: 24). Las opiniones de García y Bellido manifiestan ciertos titubeos sobre el tema (cf. Durán Cabello, 2006: e. p.). En un principio propuso que el recinto inicial se erigiría en los últimos años del siglo III o a comienzos de la siguiente centuria, adosándosele poco después el segundo (1970: 575). Posteriormente adelanta la cronología fundacional del primer encintado hasta la época flavia, momento de la instalación del campamento de la legio VII en León, mientras que la muralla de cubos se levantaría a finales del siglo III d. C. (1976: 76), siguiendo la cronología propuesta por Richmond (1931: 93-94) y Balil (1960: 192-193). Esa va ser la opinión mantenida por autores posteriores (Mateo, 1981: 14-15; Gutiérrez González, 1985: 235 y ss.; Fernández Ochoa \& Morillo, 
1992: 331-332; García Marcos, 1996: 79-80; Fernández Ochoa \& Morillo, 1999: $72-$ 73).

En la actualidad no cabe ninguna duda de que el campamento de la legio VII se amuralló en dos ocasiones. En el último cuarto del siglo I d. C., coincidiendo con la llegada de la legión a tierras leonesas, se levanta un primer recinto. Posteriormente, en época tetrárquica, se le adosa por su cara externa la muralla de cubos hoy visible.

Las excavaciones llevadas a cabo durante el año 1996 han puesto al descubierto una de las puertas pertenecientes al recinto altoimperial construido por la legio VII gemina, concretamente la porta principalis sinistra del campamento legionario. Esta construcción monumental, construida con bloques de opus quadratum, permitía el paso al recinto campamental desde el este (Fig. 5 y 6). Una puerta similar, la principalis dextra, que durante la edad Media lleva el apelativo de Cauriense, debió de existir en el extremo contrario, donde actualmente se ubica el Palacio de los Guzmanes. Ambas se unirían por medio de la via principalis, siendo la actual calle Ancha heredera de su trazado. La puerta principalis sinistra del campamento era bífora y estaba flanqueada por dos grandes torres rectangulares gemelas (García Marcos, 2002: 189-195; Morillo \& García Marcos, 2003b: 283-286; 2005).

La aparición de diversas calles, así como de la infraestructura sanitaria que en algunos casos discurre por debajo de alguna de ellas, están permitiendo reconstruir progresivamente la organización interna de espacios dentro del recinto campamental. En el eje marcado por Puerta Castillo ha sido constatada en varios lugares una superficie empedrada, restos sin duda de la via decumana. En época tardorromana debió mantenerse en uso, ya que en algunos puntos de su recorrido se procedió a realizar una nueva pavimentación. El trazado de la via quintana aún no está resuelto, aunque puede coincidir con la alineación marcada por la edificación romana exhumada parcialmente entre la Calle Serranos y el Corral de San Guisán.

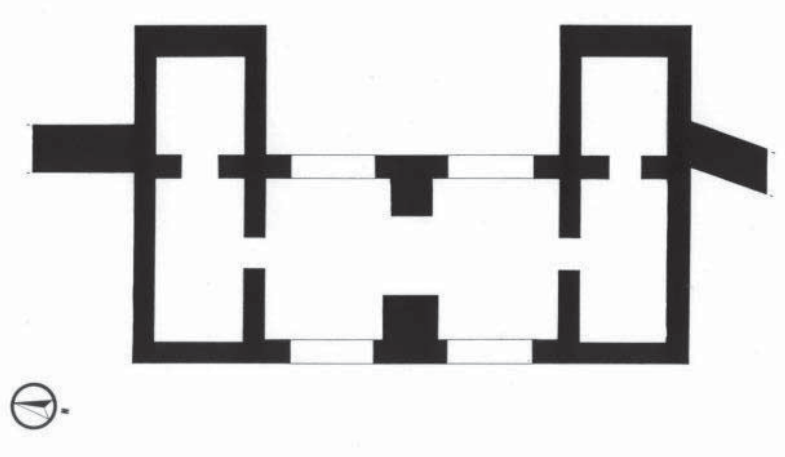

Fig. 5. Planta de la porta principalis sinistra del campamento de la legio VII gemina (según V. García Marcos). 


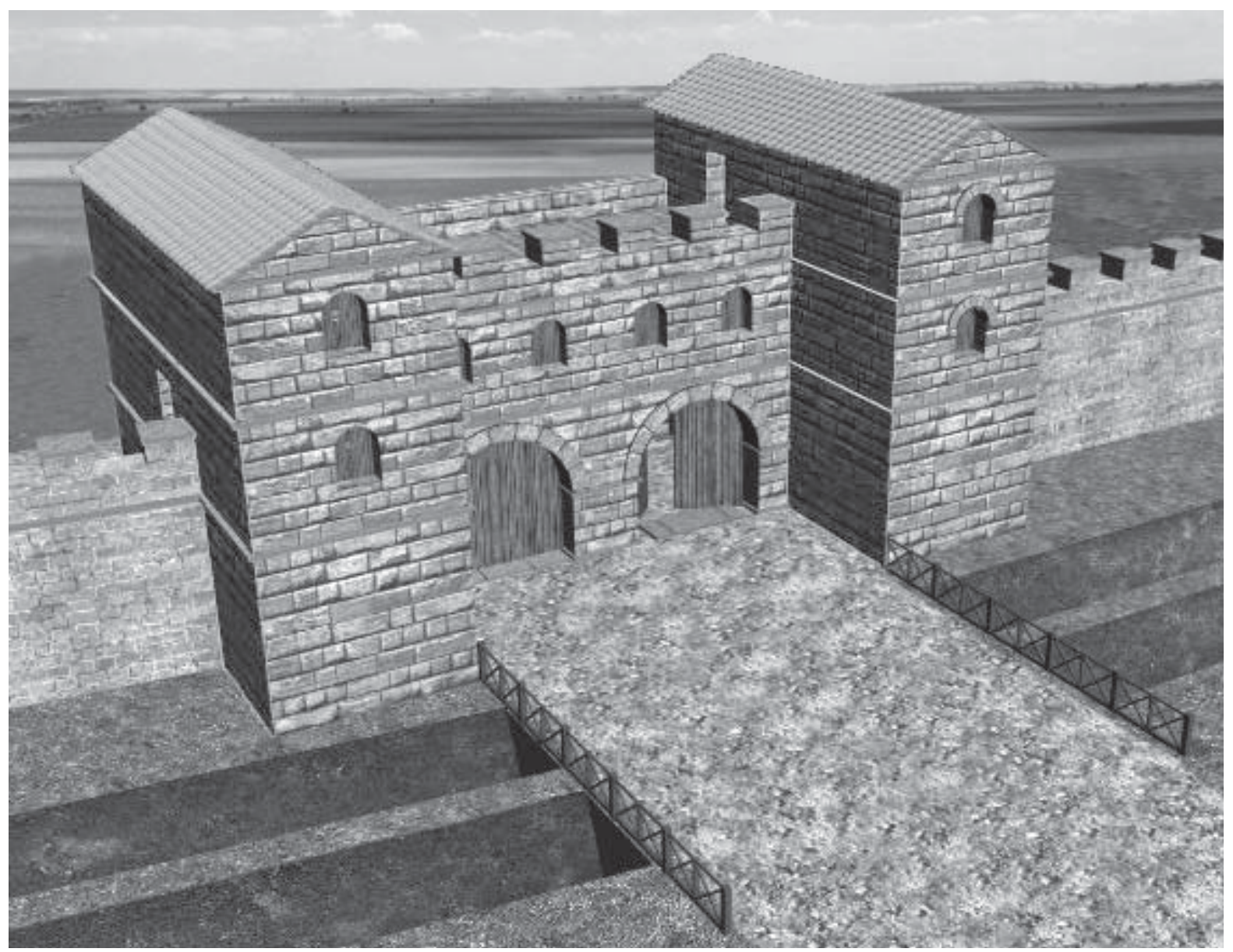

Fig. 6. Restitución virtual de la porta principalis sinistra a partir de los restos exhumados (según A. Morillo y V. García Marcos).

Existen evidencias de dos nuevas calles secundarias, viae vicinariae del campamento. Una se localizó a poniente, formando ángulo recto con la via principalis; otra en la praetentura dextra, cerca del lugar ocupado por la porta praetoria. Con una anchura de $6 \mathrm{~m}$. y dirección norte-sur, esta última estaba jalonada por varias estructuras de habitación (García Marcos, 2002: 197-198). Todo el conjunto quedó fuera de uso a finales del siglo III o comienzos del IV. El itinerario de la via sagularis ofrece pocos problemas, por cuanto corre paralela a las defensas campamentales.

La disposición interna de los espacios dentro del campamento se realiza siguiendo la modalidad per scamna, esto es, con las construcciones dispuestas en grandes áreas o zonas rectangulares paralelas a la vía principalis. Se ha detectado la presencia de cinco scamna en los que se fueron instalando las diversas estructuras. El más meridional, determinado por la via principalis y el lienzo meridional, estaría ocupado por la praetentura. Los pocos vestigios constructivos hallados hasta el momento parecen orientarse con dirección norte-sur. Aunque no existen evidencias claras respecto a qué tipo de edificios ocuparon esta área debido a la intensa transformación actual de esta zona, los paralelos ofrecidos por otros en- 
claves Legionarios como Inchtuthil, Isca Silurum, Novaesium, Bonna, Carnumtum, Lauriacum o Lambaesis abogan por la presencia de diversas centuriae o barracones dispuestos per strigas - perpendiculares a la via principalis- separados por calles secundarias (García Marcos, 2002: 184-185).

El área central del recinto, entre la via principalis al sur y la quintana al norte, configuraría los latera praetorii. Como es característica habitual en la práctica totalidad de los campamentos romanos, la posición más destacada la ocuparían los principia o cuartel general, construcción de la que desafortunadamente nada o casi nada ha podido vislumbrase hasta el momento. Tan sólo los restos de un muro de sillería y la traza de un pórtico columnado, hallados en la calle Dámaso Merino, nos esbocen quizás parte de esta edificación (García Marcos, 2002: 199). Recientemente se han documentado parte del cierre norte porticado de dicho edificio, con varias estancias interiores en torno a un pasillo que define un espacio destacado, posiblemente el aedes. Esta excavación ha proporcionado asimismo algunos fragmentos de inscripciones, una de ellas dedicada a Antonio Pío ${ }^{12}$. En este mismo sector de los latera praetorii, una reciente intervención ha identificado parte del barracón de la primera cohorte (Muñoz Villarejo et alii, 2004: e. p.).

Con menos indicios contamos aún sobre la ubicación de otras edificaciones como praetorium, valetudinarium, residencias de los tribunos y fabricae, aunque es de suponer que se dispusiesen en torno a esta zona, al menos en el caso de los tres primeros (Petrikovits, 1975: 64 y ss.).

En el extremo oriental de los latera praetorii se construyeron unas grandes termas, conservadas parcialmente bajo el subsuelo de la Catedral, de las que conocemos varias de sus estancias calefactadas mediante el sistema de hipocausto y con pavimentos musivos. Su extremo meridional debía correr paralelo a la via principalis, en las proximidades de la puerta oriental, ya que recientemente se ha identificado junto a dicho acceso una habitación que parece constituir el ángulo sureste de cierre del gran conjunto termal, ocupada en su última fase por unas grandes letrinas (García Marcos, 2002: 201; García Marcos et alii, 2004).

García y Bellido propone una fecha de mediados del siglo ॥ para estas termas, tomando como apoyo una inscripción incisa dedicada a Antonino Pío realizada en un ladrillo antes de su cocción, que apareció en el lugar (García y Bellido, 1970: 577). Esta datación parece confirmarse tras las recientes excavaciones, aunque probablemente exista una fase edilicia anterior, coincidente con la llegada de la legio VII gemina al solar leonés.

La retentura pasa por ser el espacio mejor conocido del campamento, no tanto en su planta, como por haber deparado el hallazgo de una buena parte de los escasos y fragmentarios restos constructivos conocidos hasta la fecha, hallados en las excavaciones de la zona de Santa Marina. La reciente excavación de este extenso solar ha permitido ilustrar la existencia de construcciones de dicho cuerpo mi-

12 Hemos conocido dicha evidencia epigráfica a través de las noticias en la prensa local. 
litar superpuestas a otras pertenecientes a los recintos campamentales de la legio VI (García Marcos, 2002: 199-200). El análisis de estos restos parece indicar que nos encontramos, posiblemente, ante parte de un edificio destinado al almacenaje. Su esquema cuenta con paralelos bien identificados en otras fortalezas legionarias, pudiéndose incluir dentro de los «almacenes con patio» de la clasificación de Petrikovits (1975: 85-86, fig. 20). Suelen ocupar siempre una posición excéntrica, próxima a la via sagularis, pudiendo disponerse en la praetentura (Noviomagus, Vindonissa), la retentura (Novaesium, Lambaesis) o a ambos lados de los latera praetorii (Bonna, Carnumtum).

\section{Las cannabae legionarias}

En el perímetro del campamento de la legio VII gemina se instalará un importante núcleo civil, las cannabae, consustancial a todos los castra, cuyo conocimiento preciso aún estamos lejos de atisbar. En la zona suroccidental -excavaciones de los Edificios Pallarés y Botines- la llegada de la legio VII coincide con una acumulación de tierras de textura arcillosa de casi $2 \mathrm{~m}$. de espesor, sobre la que se construyeron diversas edificaciones de uso impreciso (Miguel \& García Marcos, 1994: 194-196). Un fenómeno similar se ha detectado en el extremo contrario, donde se ha localizado un rico vertedero cuya ubicación no debió de ser fortuita, eligiéndose una zona con una amplia depresión natural, facilitándose de esta manera la concentración de los vertidos y la homogeneización topográfica del entorno del campamento (Vidal, 1999: 258). Un estudio sobre los materiales de dicho vertedero ha visto la luz recientemente (Fernández Freile, 2003).

Restos de construcciones extramuros han sido localizadas también en las proximidades de la porta principalis sinistra y al este del recinto, concretamente en la zona de San Lorenzo, reconociéndose parte de un conjunto termal de reducidas dimensiones, datado entre los años 73/74 d. C. y el principado de Septimio Severo (Vidal \& García Marcos, 1996: 149).

Una intervención realizada extramuros, a varios metros del ángulo sudoeste del recinto, ha permitido descubrir una interesante construcción, identificada con una estructura abovedada, si bien, por encontrarse totalmente aislada -al menos en la superficie del solar en que apareció- no había podido identificarse con una edificación determinada. Se trata de una galería abovedada, de unos 1,5 m. de anchura y $2,50 \mathrm{~m}$. de altura conservada, que describe una línea curva, construida con sillares regulares de caliza y arenisca, según se puede observar en el mejor conservado de sus muros. Este, que tiene $1,25 \mathrm{~m}$. de anchura, conserva el arranque de una bóveda de opus caementicium. Dicha bóveda volteaba sobre un muro de opus quadratum prácticamente desaparecido (García Marcos, 2002: 202). Los restos localizados en 2004 por la empresa Talactor en un solar próximo, que parecen formar parte del mismo edificio junto con los anteriores, han permitido identificarlo como el anfiteatro castrense (Vidal, 2005). 
Existen ciertos indicios - la continuidad de su ocupación— que nos hacen sospechar que el núcleo más importante de las cannabae legionarias debió de situarse en la zona donde siglos más tarde se emplazaría, dada su favorable orientación, el burgo medieval o Barrio de San Martín, si bien, por el momento, no existen pruebas concluyentes, debido a las todavía limitadas excavaciones arqueológicas llevadas a cabo en esta parte de la ciudad.

Por lo que se refiere al territorio circundante, recientemente se ha documentado también los restos de un acueducto romano a algunos $\mathrm{km}$ al norte del recinto amurallado. El specum de dicha construcción está construido con tegulas selladas por la legio VII (Campomanes, 2006: e. p.).

\section{El periodo tardorromano}

El hecho más significativo desde el punto de vista urbanístico durante el periodo tardorromano es la edificación de una nueva muralla que envuelve a la anterior por su cara externa hasta alcanzar una anchura total de $7 \mathrm{~m}$. Dicha erección, que tuvo lugar a finales del siglo III o comienzos del IV, alteró notablemente la fisonomía del recinto campamental altoimperial.

La edificación de la nueva muralla, al igual que sucede en el caso de la vecina Asturica, se enmarca dentro de la nueva concepción geoestratégica del Bajo Imperio romano, dentro de la cual la presencia de unidades del ejército sigue siendo imprescindible, tal y como avala la Notitia Dignitatum (XLII, 1, 25). La nueva provincia Gallaecia ocupará un nuevo e importante papel dentro de dicha concepción. Para atender las nuevas necesidades era preciso introducir cambios en la vertebración del territorio, conseguida principalmente a través de las vías de comunicación. En esta clave debe entenderse la intensa labor de adecuación y reparación viaria llevada a cabo en el norte y noroeste peninsulares durante el Bajo Imperio (Fernández Ochoa \& Morillo, 1994: 189; 1999: 104). El objetivo más evidente de esta política viaria parece ser el mantenimiento de las conexiones entre el norte y el oeste peninsulares con el sudoeste de la Galia, donde Burdigala (Burdeos) actúa como centro redistribuidor de productos. Además, se pone en comunicación la capital de la Diocesis Hispaniarum, Emerita Augusta, con el centro militar provincial — Legio VII-y, a través de Burdigala, con la capital de la prefectura de las Galias, Augusta Treverorum (Tréveris), precisamente el centro encargado del abastecimiento del limes germano (Fuentes, 1996: 215). La vertebración se produce en torno la ruta de la Plata y a las vías XXXII y XXXIV del Itinerario de Antonino, que confluyen en Asturica con las vías XVII y XVIII procedentes de la capital provincial, Bracara Augusta. La ciudad de Asturica actuaría como bisagra como un gran eje de comunicaciones que se dirige hacia el este, bien hasta Tarraco, bien, desviándose a través del territorio vascón, hacia la Galia, hasta alcanzar Burdigala. Esta ruta terrestre tendría su réplica en una ruta costera que, según el Ravennate, bordea el litoral septentrional desde Bracara hasta Ossaron (Irún) (Fernández Ochoa \& Morillo, 1999: 104-105). 
El objetivo de este complejo dispositivo habría que buscarlo en el papel desempeñado por Hispania en relación con el avituallamiento de los limites germánico y británico, principal cometido asignado a la Diocesis Hispaniarum dentro del nuevo esquema estratégico diseñado por el Estado romano para la pars occidentalis del Imperio. En áreas como la Meseta y la Lusitania se desarrolla la recaudación de impuestos en especie, principalmente cerealísticos, con destino a la annona militaris, que es preciso transportar hacia las unidades estacionadas en las fronteras germánicas y británicas, transporte que se realiza a través de vías bien cuidadas y custodiadas por unidades del ejército (Morillo, 1991: 181; Fernández Ochoa \& Morillo, 1994: 189 y 1999: 105-106).

Dentro de esta compleja concepción geoestratégica se inserta asimismo la construcción de potentes recintos defensivos en núcleos urbanos de pequeño y mediano tamaño del norte y noroeste peninsulares, que se vieron convertidos en estaciones intermedias de recaudación y tránsito de la annona. Asturica Augusta, Bracara Augusta, Lucus Augusti, Legio VII, Gijón y Veleia-Iruña, entre otras, se encuadran dentro de este contexto. Todas ellas fueron edificadas en época tetrárquica (Fernández Ochoa \& Morillo, 1992: passim; 1997; García Marcos et alii, 1997: 528; Fernández Ochoa, 1997: 87). Es significativo además que varios de los cuerpos de limitanei relacionados en la Notitia Dignitatum - legio VII gemina, cohors Lucensis y cohors I Gallica - se encuentren acantonados en tres de estas ciudades amuralladas, León, Lugo e Iruña respectivamente. La relación del elemento militar con las ciudades amuralladas no significa necesariamente que el ejército haya intervenido directamente en su construcción, tal y como se postula para provincias vecinas como la Aquitania (Maurin, 1992: 383), aunque no cabe duda de que el ejército debió desempeñar un papel fundamental en la puesta en práctica de este esquema estratégico (Fernández Ochoa \& Morillo, 1997: 738-739) ${ }^{13}$.

Las profundas transformaciones que experimentan los asentamientos del norte y noroeste peninsulares a partir de mediados del siglo III, se reflejan asimismo en el recinto militar de León y las cannabae cercanas. La brusca contracción del registro arqueológico a partir de este momento evidencia un periodo de crisis (Morillo et alii, 2002: 79). La estructura urbanística del recinto legionense durante la Tardía Antigüedad resulta por el momento prácticamente desconocida. No obstante, la magnitud de la obra de la nueva muralla, así como sus rasgos morfológicos y constructivos, típicamente militares (Fernández Ochoa \& Morillo, 1997: 738-739), además de los restos de equipo militar bajoimperial documentados en recientes excavaciones, permiten suponer que la legio VII gemina o, al menos, una parte significativa de la misma, debió de permanecer durante el siglo Iv en su antiguo campamento de León, desempeñando las nuevas funciones militares asignadas a la península ibérica. La Notitia Dignitatum sigue mencionando la presencia de la legio VII en su campamento de León a comienzos del siglo v (XLII, 1, 25).

${ }_{13}$ Sobre la inserción de las murallas bajoimperiales hispanas y del «grupo del Noroeste» en especial, dentro de la estrategia global del Imperio $v$. Fernández Ochoa \& Morillo, 1991 y 1992: passim; 1997; Fernández Ochoa, 1997: 87; Fernández Ochoa \& Morillo, 1999: 102-108; 2002). 
Diversos indicios de carácter material, recientemente identificados, entre los que se encuentra diversos restos numismáticos y de indumentaria militar, apuntan a la llegada al campamento legionario de León de nuevas tropas de la zona de Pannonia, posiblemente reasignadas a la legio VII gemina, en un momento que podemos situar a finales del siglo III. Aunque por el momento solo es posible formular algunas hipótesis sobre la procedencia de dichos militares, así como la finalidad de un traslado de tropas de estas características, no podemos dejar de señalar que este movimiento coincide temporalmente con la construcción de la muralla bajoimperial y las transformaciones sufridas por la porta principalis sinistra (Morillo \& García Marcos, 2005: 575) ${ }^{14}$. En efecto, en época tetrárquica, en coincidencia con el levantamiento de la muralla bajoimperial, se acometen profundos cambios en la puerta. La mayor parte de su estructura es desmantelada, integrándose exclusivamente dentro de la fortificación tardía los dos cuerpos avanzados.

Ya hemos señalado que la documentación arqueológica relativa al periodo tardorromano es muy escasa. Los hallazgos más significativos de este momento son las dos necrópolis de inhumación localizadas respectivamente al suroeste (entorno de la calle Monasterio) (González, 1991-92) y nordeste (Campus Universitario de Vegazana) (Liz \& Amaré, 1993) del recinto murado. La primera está situada en el lugar sobre el que más tarde se levantará uno de los monasterios más antiguos de León, el de San Claudio. Las características de las inhumaciones de este cementerio son similares a las del de Vegazana: fosas delimitadas con ladrillos o cantos y cubierta a capucina o plana, etc., si bien existe algún sarcófago de lajas. Su cronología se extendería desde el siglo IV al VII. Respecto a la necrópolis del Campus de Vegazana, se avanza una datación de los siglos IV o v, sin mayores precisiones, pues su excavación no proporcionó elementos arqueológicos precisos.

\section{BIBLIOGRAFÍA}

Abascal, J. M. (1986): «La Legio VII Gemina. Balance de la investigación y perspectivas», Actas I Congreso Internacional Astorga Romana, I, Astorga, 317-328.

Alföldy, G. (1969): Fasti Hispanienses. Senatorische Reichsbeamte und Offiziere in den spanischen Provinzen der römischer Rieches von Augustus bis Diokletian, Wiesbaden.

AuRRECOECHEA, J. (2006): «Talleres dedicados a la producción de equipo militar en los campamentos romanos de León, con especial referencia a los restos de lorica segmentata», A. Morillo (coord.), Arqueología Militar Romana en Hispania. Producción y abastecimiento en el ámbito militar, León (en prensa).

Avello, J. L. (1985): «Calle de La Abadía y Plaza de Santo Martino, León». Arqueología 83. Memoria de las Excavaciones Programadas en el año 1983, Madrid, 132.

BALIL, A. (1960): «La defensa de Hispania en el Bajo Imperio», Zephyrus XI, 179-197.

CAMPOMANES, E. (1997): «Algunas cuestiones en torno a la primera muralla de la Legio VII Gemina», Lancia 2, 129-148.

CAmpomanes, E. (1998/99): «Hallazgo de un complejo metalúrgico romano en la ciudad de León. Excavaciones en la calle Plegarias con vuelta a la calle Ramiro III en la ciudad de León, Lancia 3, 269-280.

14 Los datos estratigráficos que sustentan esta interpretación se encuentran en fase de publicación dentro de nuestro Proyecto del MCYT BHA2002-03305. 
CAmpomanes, E. (2006): «El acueducto romano de León y las producciones latericias», A. Morillo (coord.), Arqueología Militar Romana en Hispania. Producción y abastecimiento en el ámbito militar, León (en prensa).

Campomanes, E.; Muñoz Villarejo, F. y Álvarez Ordás, J. C. (2002): «Ocupaciones militares anteriores a la llegada de la legio VII gemina a la ciudad de León», A. Morillo (coord.), Arqueología Militar Romana en Hispania, Anejos de Gladius 5, Madrid, 339-348.

CARRetero, S. y Romero CARnicero, M. ${ }^{a}$ V. (1996): Los campamentos romanos de petavonium (Rosinos de Vidriales), Zamora.

Diego SANTOS, F. (1986): Inscripciones romanas de la provincia de León, León.

Domergue, C. (1986): «Dix-huit ans de recherche (1968-1986) sur les mines d'or romaines du nord-ouest de la Péninsule Ibérique», I Congreso Internacional Astorga Romana II, 7-101, Astorga.

Durán Cabello, R. M. (2006): «La arquitectura militar romana en la obra de García y Bellido. Notas sobre sus intervenciones arqueológicas en Herrera de Pisuerga y León», A. Morillo (coord.), Arqueología Militar Romana en Hispania. Producción y abastecimiento en el ámbito militar, León (en prensa).

FERnÁNDEZ AlLeR, M. ${ }^{a}$ C. (1982): «Un grafito latino hallado en la muralla romana leonesa», Estudios Humanísticos 4, 163-188.

FERnÁNDEZ Freile, B. E. (2003): La época romana en León. Aspectos arqueológicos. Estudio arqueológico de un vertedero romano situado en la calle Maestro Copín c/v San Salvador del Nido en la ciudad de León, León.

FERNÁNDEZ OCHOA, C. (1995): «Astures y Roma: la configuración del territorio», Catálogo de la Exposición Astures, Gijón, 99-111.

FERnÁNDEZ OCHOA, C. y MoRILLO, A. (1992): «Fortificaciones urbanas de época bajoimperial en Hispania. Una aproximación crítica (segunda parte)», CUPAUAM 19, 319-360.

- (1994): De Brigantium a Oiasso. Una aproximación al estudio de los enclaves marítimos cantábricos en época romana, Madrid.

- (1997): «La muralla de Iruña en el contexto de las fortificaciones urbanas bajoimperiales de la región septentrional de la Península Ibérica», Isturitz 9 (I Coloquio Internacional sobre la Romanización en Euskal Herria, Donostia, 1996), Donostia, 735-742.

- (1999): La Tierra de los Astures. Nuevas perspectivas sobre la implantación romana en la antigua Asturia, Gijón.

- (2002): «Entre el prestigio y la defensa: la problemática estratégico-defensiva de las murallas tardorromanas en Hispania», A. Morillo (coord.), Arqueología Militar Romana en Hispania, Anejos de Gladius 5, Madrid, 577-590.

- (2005): «Walls in the Urban Landscape of Late Roman Spain. Defense and Imperial Strategy», K. Bowes y M. Kulikowski, M. (eds.) Hispania in the Late Antique World. Twenty-First Century perspectives, Leiden (299-340).

Fernández-Posse, M. D. y SÁnchez-PALEnCIA, J. (1988): La Corona y el Castro de Corporales II. Campaña de 1983 y prospecciones en La Valdería y La Cabrera, Excavaciones Arqueológicas en España 153, Madrid.

FUeNTES, A. (1996): «La romanidad tardía en los territorios septentrionales de la Península Ibérica», C. Fernández Ochoa (coord.), Coloquio Internacional de Arqueología: los finisterres atlánticos en la antigüedad (época prerromana y romana), Gijón, 213-227.

García y Bellido, A. (1950): «La Legio VII Gemina Pia Felix y los orígenes de la ciudad de León», BRAH 227, 449-479.

— (1961): «El «Exercitus Hispanicus» desde Augusto a Vespasiano», AEspA 34, 114-160.

- (1970): «Estudios sobre la Legio VII Gemina y su campamento en León», Legio VII Gemina, León, 569-599.

- (1970b): «Nacimiento de la Legio VII Gemina», Legio VII Gemina, León, 303-329.

- (1975): «El llamado «Itinerario de Barro», BRAH 172, 3, 547-563.

- (1976): «El ejército romano en Hispania», AEspA 49, 59-101.

- et alli (1987): Resumen Histórico del Urbanismo en España, Madrid (1. a ed. 1954).

García de Figuerola, M. y GonzÁlez Alonso, E. (1998/99): «Las contramarcas monetarias de la legio VI en Hispania», Lancia 3, 127-140.

García Marcos, V. (1986): Estudio sobre la Terra Sigillata Hispánica hallada en la ciudad de León, Tesis de Licenciatura, inédita.

- (1989/1990): «Marcas de alfarero en Sigillata Hispánica halladas en la ciudad de León», Tierras de León 77-78, 89-114.

- (1994): Descubrimiento de unas nuevas termas públicas de Asturica Augusta (Astorga, León), Cuadernos Municipales 2, Astorga. 
- (1996): «La romanización urbana: Asturica Augusta y la implantación romana en León», ArqueoLeón. Historia de León a través de la arqueología, Valladolid-León, 69-81.

- (2002): «Novedades acerca de los campamentos romanos de León», A. Morillo (coord.), Arqueología Militar Romana en Hispania, Anejos de Gladius 5, Madrid, 167-212.

- (2005): «Importación de terra sigillata itálica y producciones locales de tradición itálica en la Meseta norte y el Noroeste peninsular», C. Fernández Ochoa y P. García Díaz (eds.), III Coloquio Internacional de Arqueología en Gijón: Unidad y diversidad en el Arco Atlántico en época romana (Gijón, 2002), BAR Int. Series 1371, Oxford, 87-108.

García Marcos, V. y Miguel, F. (1997): «A new view on the military occupation in the North-West of Hispania during the First Century: the case of León», Proceedings of the XVI International Congress of Roman Frontier Studies, Oxbow Monograph 91, 355-360.

García Marcos, V., Miguel, F. y Campomanes, E. (2004): «El solar y el entorno urbano de Santa María de Regla (ss. I-XV)», Congreso Internacional: La Catedral de León en la Edad Media, León, 23-44.

García Marcos, V. y MorilLo, A. (2000/01): «El campamento de la legio VII gemina en León. Novedades sobre su planta y sistema defensivo", Lancia 4, 103-126.

- (2002): «The legionary fortress of VI Victrix at León (Spain). The new evidence», Limes XVIII. Proceedings of the XVIIIth International Congress of Roman Frontier Studies (Amman, 2000), Bar Int. Series 1084 (II), Oxford, 791-800.

García Marcos, V. y VIDAL Encinas, J. (1995): «Asturica Augusta y Castra Legionis VII Geminae en la Asturia Cismontana», Catálogo Exposición Astures, Gijón, 113-128.

Gómez-Moreno, M. (1925): Catálogo Monumental de España. Provincia de León (1906-1908), Madrid.

GonZÁlez Alonso, E. (2002): «Documenta ad Asturicae Augustae Historiam Ilustrandam», en Amaré M${ }^{a}$ T. (dir.): Astorga l: contexto geográfico e histórico, León, 51-86.

GonzÁLEZ FERnÁNDEZ, M. L. (1991-92): «Necrópolis tardorromana en el solar del Monasterio de San Claudio de León», Nvmantia 5, 107-126.

- (1996): «Consideraciones sobre el origen militar de Asturica Augusta», C. Fernández Ochoa (coord.), Coloquio Internacional de Arqueología: los Finisterres Atlánticos en la Antigüedad, Gijón , 85-90.

Gutiérrez, J. A. (1985): Poblamiento Antiguo y Medieval de la Montaña Central Leonesa, León.

Le Roux, P. (1982): L'armée romaine et l'organisation des provinces ibériques d'Auguste a l'invasion de 409, Paris.

LIZ, J. y AMARÉ, Ma T. (1993): Necrópolis tardorromana del Campus de Vegazana y las producciones latericias de la Legio VII Gemina, León.

LUENGO, J. M. (1956/61): «Astorga romana. Excavaciones del Plan Nacional 1954-1955», NAHisp V, 152177.

Mañanes, T. (1976): «Asturica Augusta», Symposion de Ciudades Augusteas II, Zaragoza, 77-84.

- (1982): Epigrafía y numismática de Astorga romana y su entorno, Salamanca.

- (1983): Astorga romana y su entorno. Estudio arqueológico, Valladolid.

- (1983/84): "Asturica Augusta, la ciudad y su entorno», Portugalia IV-V (Actas do Coloquio Interuniversitario de Arqueologia do Noroeste), 215-229.

MARTín HeRnÁndez, E. (2006): Cerámica romana de paredes finas en el campamento julio-claudio de la legio VI victrix procedente del polígono de la Palomera, León (en prensa).

MATEO, J. (1981): Origen, Evolución y Decadencia del Recinto Amurallado de León, León.

MAURIN, L. (1992): «Remparts et cités dans les trois provinces du Sud-Ouest de la Gaule au Bas-Empire (dernier quart du Ille siècle-début du Ve siècle», Villes et agglomérations urbaines antiques du SudOuest de la Gaule. Histoire et Archéologie, Aquitania Sixiènne suppl., Burdeos.

Miguel Hernández, F. y García Marcos, V. (1994): «Intervención arqueológica en el patio del Centro Cultural Pallarés (León)», Nvmantia 4, 175-206.

MoRILLO, A. (1991): «Fortificaciones campamentales de época romana en España», AEspA 64, 135-190.

- (1996): «Campamentos romanos en la Meseta Norte y el Noroeste: ¿un limes sin frontera?», C. Fernández Ochoa (coord.), Coloquio Internacional de Arqueología: los finisterres atlánticos en la antigüedad (época prerromana y romana), Gijón, 77-84.

- (1998): «Militares y civiles en el origen del fenómeno urbano en el Norte y Noroeste peninsulares», Congreso Internacional sobre los orígenes de la ciudad en el Noroeste hispánico (1996) I, Lugo, 339354.

- (1999): Lucernas romanas en la región septentrional de la Península Ibérica. Contribución al conocimiento de la implantación romana en Hispania, Monographies Instrumentum 8, Montagnac.

- (1999b): «Asentamientos militares y civiles en el origen del fenómeno urbano en el Norte y Noroeste peninsulares», Congreso Internacional sobre los orígenes de la ciudad en el Noroeste hispánico (1996), Lugo, 339-354. 
- (1999c): «Contramarcas militares en monedas de la Submeseta Norte. Algunas consideraciones generales», Anejos AEspA XIX (Actas II Encuentro Penínsular de Numismática Antigua, Oporto, 1998), Madrid, 71-90.

- (2000): «La legio IIII Macedonica en la Península Ibérica. El campamento de Herrera de Pisuerga (Palencia), Ile Congrés de Lyon sur l'armée romaine. Les légions de Rome sous le Haut Empire (1998), Lyon, 609-624.

- (2000b): «Neue Forschungen zu römischen Lagern der iulisch-claudischen Zeit in Nordspanien», Bonner Jahrbücher 200, 1-24.

- (2002): «Conquista y estrategia: el ejército romano durante el periodo augusteo y julio-claudio en la región septentrional de la península ibérica», A. Morillo (coord.), Arqueología Militar Romana en Hispania, Anejos de Gladius 5, Madrid, 67-94.

- (2006): «Abastecimiento y producción local en los campamentos romanos de la región septentrional de la península ibérica», A. Morillo (coord.), Arqueología Militar Romana en Hispania. Producción y abastecimiento en el ámbito militar, León (en prensa).

- (2006b): «Los Dióscuros y la legio VII gemina. Algunas reflexiones sobre el apelativo y el emblema de la legión", A. Morillo (coord.), Arqueología Militar Romana en Hispania. Producción y abastecimiento en el ámbito militar, León (en prensa).

Morillo, A., Amaré, M. ${ }^{a}$ T. y García Marcos, V. (2005): «Asturica Augusta como centro de producción y consumo cerámico", C. Fernández Ochoa y P. García Díaz (eds.), III Coloquio Internacional de Arqueología en Gijón: Unidad y diversidad en el Arco Atlántico en época romana (Gijón, 2002), BAR Int. Series 1371, Oxford, 139-161.

Morillo, A. Y García MARCos, V. (2000): «Nuevos testimonios acerca de las Legiones VI victrix y X gemina en la región septentrional de la Península Ibérica», Actas Deuxième congrès de Lyon sur l'armée romaine: Les légions de Rome sous le Haut-Empire, II, Lyon, 589-607.

- (2001): «Producciones cerámicas militares de época augusteo-tiberiana en Hispania», Rei Cretariae Romanae Fautores. Acta 37, Abingdon, 147-156.

- (2002): «Twenty years of Roman military archaeology in Spain», Limes XVIII. Proceedings of the XVIIIth International Congress of Roman Frontier Studies (Amman, 2000), Bar Int. Series 1084 (II), Oxford, 779-789.

- (2003): «Importaciones itálicas en los campamentos romanos del norte de Hispania durante el periodo augusteo y julioclaudio", Rei Cretariae Romanae Fautores. Acta 38, Abingdon, 2003, 295-304.

- (2003b): «Legio VII Gemina and its Flavian fortress at León», Journal of Roman Archaeology 16, 275286.

-(2004): «Arqueología romana en la ciudad de León: balance de dos décadas de excavaciones», Antonio García y Bellido y su legado a la arqueología española (1903-1972). Miscelánea, Madrid, 263291.

- (2004b): «Los campamentos romanos de León: introducción histórica y arqueológica», Ma P. GarcíaBellido (ed.), Circulación monetaria en los campamentos del norte y noroeste durante el siglo I d. C., Madrid (en prensa).

- (2005): «The defensive system of the legionary fortress of VII gemina at León (Spain). The porta principalis sinistra», Linies XIX, Proceedings of the XIXth International Congress of Roman Frontier Studies, Pécs (569-583).

- (2006c): "La arqueología urbana en Asturica Augusta (1989-1995). Aproximación a una lectura cronoestratigráfica de la capital astur», Lancia 6 (en prensa).

- (2006d): «El origen militar de Asturica Augusta a través de los datos estratigráficos», Madrider Mitteilungen (en prensa).

Morillo, A., García Marcos, V. y Fernández OchoA, C. (2002): Imágenes de Arqueología leonesa. Antonio García y Bellido y el Noroeste peninsular en la Antigüedad, Valladolid.

muñoz Villarejo, F., Campomanes, E., San Roman, F. Martín, P. (2004): «Nuevos hallazgos en el campamento de la legio VII gemina y su entorno", A. Morillo (coord.), Arqueología Militar Romana en Hispania. Producción y abastecimiento en el ámbito militar, León (en prensa)

PALOL, P. DE (1976): «Perduración de las ciudades augustéas en la zona Norte y la Meseta», Symposion de Ciudades Augusteas I, Zaragoza, 263-288.

PARKER, H. M. D. (1928): The roman legions, (reed. 1993), New York.

PAstoR, M. (1976b): «Asturica Augusta ¿Fundación de Augusto?», Symposion de Ciudades Augusteas, II, Zaragoza, 69-76.

PETRIKOVITS, H. v. (1975): Die Innenbauten römischer Legionslager während der Prinzipatszeit, Abhandlungen der Rheinisch-Westfälischen Akademie der Wissenschaften 56, Oppladen.

RABANAL, M. A. (1988): Vías romanas de la provincia de León, León. 
RICHMOND, I. A. (1931): «Five town-walls in Hispania Citerior», JRS 21, 86-100.

De Los Ríos, D. (1895): La Catedral de León, (2 vols.), Madrid.

RIsco, M. (1784): España Sagrada XXXIV. Contiene el estado antiguo de la santa iglesia de León, Madrid (facs. León, 1987).

- (1792): Historia de la ciudad y corte de León y de sus reyes, Madrid (facs. León, 1987).

RITTERLING, E. (1925): «Legio», RE XII, 2.

RoldÁN HERVÁs, J. M. (1972/73): «Las Tablas de Barro de Astorga ¿una falsificación moderna», Zephyrus 23-24, 221-232.

- (1974): Hispania y el ejército romano, Salamanca.

- (1986): «La ocupación romana de la Asturia Augustana y la fundación de Astorga», Actas I Congreso Internacional de Astorga Romana, Astorga, 37-53.

SÁNCHEZ-PALENCIA, F. J. (1983): «Explotaciones auríferas en el Conventus Asturum», Indigenismo y Romanización en el Conventus Asturum, Madrid-Oviedo, 69-87.

Sánchez-Palencia, F. J. y Fernández Posse, M. ${ }^{a}$ D. (1985), La Corona y el Castro de Corporales I. Truchas (León), Campañas de 1978 a 1981, ExcArqEsp 131, Madrid.

SANTANDER, M. (1970). «Notas sobre el acueducto romano de León», BSAA 36, 467-474.

SCHULTEN, A. (1943): Los cántabros y astures y su guerra con Roma, Madrid.

Tranoy, A. (1981): La Galice romaine. Recherches sur le nord-ouest de la péninsule ibérique dan's l'Antiquité, Paris.

VV. AA. (1970): Legio VII Gemina, León.

VIDAL, J. Y GARCíA MARCOS, V. (1996): «Novedades sobre el origen del asentamiento romano de León y la legio VII gemina», Coloquio Internacional de Arqueología: los finisterres atlánticos en la antigüedad (época prerromana y romana), Gijón, 147-156.

VIDAL, J. (2005): «Notas sobre el anfiteatro romano de León», Astorica 24, 55-66. 